\title{
LUKÁCS E ORTEGA, A MODERNIDADE E A FRAGMENTAÇÃO - PRODUÇÃO DA ARTE E AÇÃOO DOS HOMENS DE CULTURA NOS ANOS 20 E 30 DO SÉCULO XX
}

\author{
Ana Lúcia Lana Nemi \\ Cátedra Jaime Cortesão - FFLCH/USP \\ Pós-doutoramento/Fapesp
}

\section{Resumo}

O objetivo deste texto é pontuar um dos conteúdos do debate das elites eruditas do início do século XX: o tema do intelectual como guardião da cultura e dos valores universais frente à barbárie que se configurara no final do XIX e que voltava a se desenhar com a ascensão dos fascismos. Para isso, destacamos as teses sobre a cultura de José Ortega y Gasset e procuramos analisá-las a partir de sugestões lukacsianas.

\section{Pallavras-Chave}

Intelectual • Modernização • Arte

\section{Abstract}

This article discusses one of the issues debated by the erudite elites in the beginning of the twentieth century: the theme of the intellectual as a guardian of culture and of universal values against the barbaric tendencies identified at the end of the nineteenth century and which reemerged with the rise of Fascism. The author analyzes Jose Ortega y Gasset's theses on culture from the perspective of the works of George Lukács.

\section{Keywords}

Intellectual • Modernization • Art 
O ponto de partida deste texto é a idéia de que Georg Lukács e José Ortega y Gasset são autores que procuraram responder a uma questão colocada pela crise do início do século XX: como recuperar a capacidade de ação consciente do homem no mundo das massas? Podemos afirmar, radicalizando um argumento de Eduard Ranch, quando aponta a existência de "cierto tono generacional entre Lukács e Ortega" porque os dois pensadores partem do pressuposto de que sua sociedade é deficitária "desde el punto de vista de la ontología del ser social"1, que os dois autores procuram respostas para o fenômeno da ascensão das massas no século XIX e sua conseqüente precipitação para o plano da ação política no início do século XX. Mas o conteúdo das análises procedidas pelos autores e seus respectivos projetos políticos caminham em sentidos opostos. Para discutir esses caminhos opostos, destacamos o tema da produção da arte e do papel dos homens de cultura nos anos 20 e 30 do século XX.

Segundo Lukács, na concepção marxista de Literatura assume grande importância o "princípio da desigualdade de desenvolvimento na determinação das peculiaridades de qualquer período". Mais ainda:

"No que concerne à história das ideologias, o materialismo histórico reconhece (...) que o desenvolvimento das ideologias não acompanha mecanicamente e nem segue 'pari passu' o grau de desenvolvimento econômico da sociedade."

Com base nesse suposto desenvolvido por Lukács é que pretendemos apresentar uma possível análise do texto orteguiano. A discussão sobre a inserção da cultura nos processos de produção da subsistência remonta ao século XIX ${ }^{3}$ e foi

\footnotetext{
${ }^{1}$ RANCH, Eduard. “Georg Lukács y Ortega en 1923”, In: Cuadernos de filosofia i ciencia, $n^{\circ} 15-16$, Universidad de Valência, 1989, p. 238. Cabe lembrar que o autor, embora não cite especificamente sua fonte ao definir o termo "tom geracional" citado acima, parece-nos estar utilizando uma terminologia orteguiana que conceitua a geração na História segundo os problemas vitais enfrentados por um conjunto de homens que, deliberadamente, propõem-se a buscar caminhos políticos para tais problemas, mesmo que apontando para soluções diferentes.

${ }^{2}$ LUKÁCS, G. Ensaios sobre Literatura. Rio de Janeiro: Civilização Brasileira, 1965, p. 17-19.

${ }^{3}$ Sobre as relações entre produção cultural e produção da subsistência no pensamento de José Ortega y Gasset veja-se a biografia intelectual de Ortega elaborada por Julián MARÍAS em Ortega, circunstancia y vocación, Madri, Alianza Editorial, 1986; e a trajetória intelectual e política de Ortega elaborada por Antonio ELORZA em La razón y la sombraUna lectura política de Ortega y Gasset. Barcelona: Anagrama, 1984.
} 
fundamental para a elaboração do pensamento culturalista de Ortega y Gasset. É nessa direção que buscamos analisar sua produção e, também, sugerir um paralelo com a produção lukacsiana das três primeiras décadas do século XX.

Assim, supondo o solo histórico como elemento fundamental para a constituição das idéias e admitindo a possibilidade das idéias apresentarem elementos de decodificação da realidade, mesmo que esses elementos não estejam claramente expressos na realidade observada, estamos propondo uma metodologia de análise do pensamento orteguiano cuja fonte é a produção lukacsiana. As ambigüidades que caracterizam o discurso liberal orteguiano originam-se, segundo acredita-se aqui, na própria constituição do capitalismo na Espanha que se desenvolveu de maneira contraditória porque mesclou elementos do "atraso" e elementos da modernidade. Nesse contexto de ambigüidade da própria vida social é que Ortega produziu seu discurso.

\section{Da arte como pedagogia social à arte como distanciamento da realidade negada}

"Sus estudios en Alemania llegaron a persuadirle de que el bienestar político y social está fundado en la cultura, y, por consiguiente, que la revitalización política de España había de basarse en un replanteamiento cultural. "“4

A atuação política orteguiana pode ser caracterizada como uma "precipitação" pública de seu conceito de cultura, envolvendo este os conceitos de homem, arte e circunstância. Ortega conceituava o homem segundo sua "circunscrição" em uma determinada cultura. Neste sentido, a vida humana deveria se definir em função de sua "socialização cultural", ou seja, o indivíduo se manifestaria em sociedade segundo um pensamento científico, ético e estético aprendido socialmente. Utilizando-se dessa conceituação que considera a cultura como elemento ordenador da vida política e social, Ortega procurava combater o "utilitarismo positivista" que caracterizara o pensamento europeu no final do século XIX e que fora, segundo ele, herança da democracia burguesa desenvolvida no mesmo período.

${ }^{4}$ INMAN FOX, E. Ideología y política en las letras de fin de siglo (1898). Madri: EspasaCalpe, 1988. 
A arte, no pensamento orteguiano jovem, era considerada uma dimensão da cultura cuja principal característica era a de ser um elemento de liberação da realidade. Dentro deste contexto, ela deveria retirar a realidade de sua trivialidade quotidiana para conferir-lhe representação e simbologia. A experiência de observar a obra-de-arte assume assim, caráter histórico e político, na medida em que a arte tem a função social de "educar" as "massas" através das "propostas" apresentadas pelos artistas em seus trabalhos.

Esse "Idealismo Político" caracterizou toda a atuação política de Ortega nas três primeiras décadas do século XX: a obra-de-arte não poderia ser considerada como patrimônio individual, ela deveria criar uma totalidade fictícia que pudesse educar as "massas".

O desenvolvimento do conceito de circunstância, especialmente a partir da publicação das "Meditaciones del Quijote" em 1914, ao contrário do que pensam autores como Cerezo-Galán e Inman Fox ${ }^{6}$, não parece ter sido suficiente para que Ortega superasse esse idealismo que manifestou, acreditamos, em sua vida pública até o início da Guerra Civil em 1936. A "vida cultural" deixou de ser considerada fundamental, mas não perdeu sua importância na configuração da "vida humana" em sua dimensão "circunstancial". Ortega definiu a cultura a partir da circunstância e elegeu Espanha como primeiro elemento formador de suas reflexões, mas não deixou de considerar a existência e a importância da divulgação de determinados princípios concebidos como norteadores da vida pública de cada sociedade. A cultura continuaria sendo um "repertório de soluções" possíveis para responder às necessidades humanas?. Este conceito de arte notadamente dinâmica e inventiva acabou por aproximálo das vanguardas artísticas do início do século, movimentos culturais nos quais enxergava uma vontade revolucionária de superar sua época histórica.

A obra de arte, enquanto proposta ou solução possível para os problemas humanos, expressaria uma relação específica entre o "yo" e a circunstância que se manifestaria em uma intenção de alterar a ordem sociopolítica vigente.

\footnotetext{
${ }^{5}$ SALMERÓN, F. Las mocedades de Ortega y Gasset. Cidade do México: Universidad Autónoma de Máxico, 1983.

${ }^{6}$ ORTEGA Y GASSET, J. “Meditaciones del Quijote”, In: Obras Completas, vol. I, Madri: Alianza Editorial, 1987. CEREZO-GALÁN, P. "Razón vital y liberalismo en Ortega y Gasset”, In: Revista de Occidente, Madri, maio-1991, nº 120.

${ }^{7}$ INMAN FOX, E., op. cit., p. 368-369.
} 
Vontade para realizar tal obra-de-arte, Ortega encontrou na "Arte Nova", denominação que escolheu para identificar as novas expressões artísticas de vanguarda que procurou definir no texto "La deshumanización del arte" de $1925^{8}$. Neste, Ortega pretendeu demonstrar que o homem e o "homem-massa" possuem reações diferentes frente à arte, sendo que aquele utilizaria a invenção artística como forma de opinar e este utilizaria simplesmente a caricatura.

Ortega definiu, em torno da "arte nova", sua impopularidade quando comparada ao Romantismo do século XIX, notadamente popular. Diante de uma obra romântica era possível à "massa" reconhecer-se na trama proposta pelo artista, o que desde logo possibilitava uma identificação. Com a "arte nova" ocorreria exatamente o contrário. A "massa" não se enxergaria na obra precisamente porque a "arte nova" não se constituiria de elementos humanos representados segundo sua realidade factível. Para o observador de tal obra seria necessária capacidade de compreensão. Não bastaria “viver” a obra, seria preciso contemplá-la à distância:

"Lo característico del arte nuevo es que divide al público en estas dos clases de hombres: los que lo entienden y los que no lo entienden."

A "arte nova" dirigia-se, neste sentido, a uma "minoria" e não à "massa". Cabe então definir quais são seus elementos diferenciadores frente ao Romantismo que levaram Ortega a afirmá-la como arte para "minoria".

É preciso estabelecer que, para Ortega, um objeto será obra-de-arte apenas na medida em que, ao engendrar uma proposta/projeto, não for real. Dentro desta conceituação, seria possível encontrar um objeto artístico, com características reais/humanas, ou uma obra-de-arte, quando desvinculada da percepção humana do mundo. A "arte nova” propor-se-ia a negar o real, a superá-lo através da retratação artística, o que configuraria uma tendência a racionalizar e desumanizar a arte.

O que buscariam os artistas novos, seria fugir às representações reais, ou seja, retirar o olhar humano da realidade de suas obras. Ortega não chega a formular claramente a tese, mas seu texto parece apontar para a existência de

\footnotetext{
${ }^{8}$ Ibidem.

${ }^{9}$ ORTEGA Y GASSET, J. "La deshumanización del arte”, In: Obras Completas, vol. III, op. cit., p. 355.
} 
duas dimensões do olhar humano sobre a realidade, um primeiro olhar que apenas apresenta e descreve o real, e um outro olhar que busca interpretações e soluções que pretendem superar o real.

O artista de Ortega manifesta sua criação por meio da utilização de uma emoção secundária ao simples viver as coisas, é aquele que, por meio da obra de arte, triunfa sobre as limitações da condição humana. Este triunfo se constituiria em criar algo irreal e, ao mesmo tempo, substancial em seu conteúdo. A nova intenção artística enaltecida por Ortega, deveria mundificar a idéia, pois realizar a idéia seria o mesmo que realizar o irreal ${ }^{10}$.

Ortega acreditava que os "novos artistas", por meio da realização de idéias/ projeto em obra-de-arte, poderiam, e deveriam, superar a obra-de-arte/caricatura que, segundo ele, havia sido desenvolvida pelos românticos. Talvez os modernistas tenham realmente superado uma certa tendência da novela romântica que caricaturava os comportamentos através dos personagens. No entanto, a visão romântica da vida enquanto superação dos limites do homem consubstanciada na Espanha pelo mito do Quixote - , não parece estar muito distante do desejo orteguiano de superar a realidade circundante através da obra-de-arte que denuncie "idéias/projeto".

É de se destacar a profunda diferença entre o pensamento orteguiano e a crítica tradicional do modernismo. Enquanto estes últimos criticavam o modernismo por seu excessivo apego à estética e pouca consideração para os problemas humanos, Ortega apontava esta mesma estética como sintoma positivo de projeção de uma nova realidade. ${ }^{11}$

Em seus escritos de juventude ${ }^{12}$ já apontava Ortega para essas questões afirmando que o político não estaria na palavra usada, mas na intenção do poeta. A

\footnotetext{
${ }^{10}$ Ibidem, p. 376.

${ }^{11}$ Sobre este tema cabe destacar a bibliografia que compara a produção dos modernistas com a da geração de 1898, cujos conteúdos e temas foram partilhados por Ortega. Esses autores apontavam a geração de 98 como um grupo preocupado com as questões sociais mais importantes para o homem enquanto os modernistas eram reduzidos a preocupações de caráter puramente "estetizante". Cabe citar: DÍAS-PLAJA, G. Modernismo frente al noventa y ocho. Madri: Espasa-Calpe, 1966; JESCHKE, H. La generación de 1898 en España - Ensayo de una determinación de su esencia. Santiago de Chile: Ediciones de la Universidad de Chile, s.d.

${ }^{12}$ ORTEGA Y GASSET, J. “Moralejas”, In: Obras Completas, op. cit., vol. I, p. 44-57.
} 
palavra seria apenas o instrumento para se trabalhar a matéria da arte. Desumanizar a arte estaria em preocupar-se com a idéia e não com a sua manifestação em signos. Estes se constituiriam no humano, no particular, no sentimento individual. $\mathrm{O}$ artista deveria procurar os sentimentos universais, além de particularismos.

Inventar o que não existe. Inventar a partir do humano, da contemplação dos limites humanos para em seguida superá-los - o instrumento seria a metáfora, não como ornamento, mas como substância. Inventar, seria esta a função social da arte no pensamento orteguiano? Em 1904 Ortega afirmava que "la estética es una cuestión política" ${ }^{13}$, poderia trazer em si toda a história de um povo, "el respecto y el amor al pasado" 14 de onde se poderia retirar "la audacia del pensar científico o artístico" 15 , características que não se encontrariam na arte da Espanha. Ortega jovem queria uma arte cuja função fosse educar e esclarecer o povo. Em "Adán en el Paraíso", de 1910", aprofundou estes apontamentos: a arte possuiria a função universal de traduzir as "coisas", a vida e a relação de ambas com o homem.

Percebe-se uma evolução do conceito de arte no que diz respeito à sua função social. No primeiro artigo de juventude o artista foi apresentado como um ente nacional, sua função era traduzir um drama nacional por meio de sua arte. No artigo de 1910, o artista tornou-se um ser universal. Nos dois artigos porém, a origem das discussões estéticas encontrava-se no problema de Espanha - de onde decorria seu interesse pela obra de Zuloaga, diante da qual não se poderia deixar de pensar no destino da Espanha $^{17}$ - , a arte era apenas mais um recurso para se problematizar Espanha.

Em "La deshumanización del arte" de 1925, Ortega constatou a existência de um artista novo vinculado a determinada época histórica e articulou suas idéias como que para compreendê-lo. O artista novo, parecia-lhe, agredia a tradição da arte e, por consequiência, a tradição histórica européia. Esta se tornou, então, a questão central de sua conceituação de arte: desumanizar a arte,

\footnotetext{
${ }^{13}$ Idem, "Las fuentecitas de Nuremberga", In: Obras Completas, op. cit., vol. I, p. 425-429.

${ }^{14}$ Ibidem.

${ }^{15}$ Ibidem.

${ }^{16}$ Idem, “Adán en el Paraíso”, In: Obras Completas, op. cit., vol. I, p. 473-493.

${ }^{17}$ Idem, "Una exposición Zuloaga?”, In: Obras Completas, op. cit., vol. I, p. 139-141.
} 
querer destruir a tradição da arte - que lhe fora tão cara nos primeiros anos de estudos na Institución Libre de Enseñanza - , não seria uma forma de negar o passado europeu e seus produtos sociais? Ao mesmo tempo em que fazia esta pergunta, Ortega enaltecia a "arte nova", o que permite indagar se o seu desejo maior não seria exatamente o de conferir à arte o caráter político de negação da realidade européia daqueles anos 20.

A "arte nova" interessava a Ortega porque lhe parecia manifestar-se, e de fato assim o era, a partir de uma constatação política que não aceitava a organização social da Europa tal como se encontrava naquele início de século e por isso tentava superá-la artisticamente.

É possível uma relação dialética em que a arte exista através da negação e da continuidade de sua própria historicidade? Ao mesmo tempo em que tecia elogios à "arte nova", na qual enxergava uma vontade de destruir a tradição, Ortega inseria esta mesma arte no que considerava ser o seu verdadeiro caminho histórico: a vontade de estilo, a vontade de criar algo novo de fato, algo voltado para o futuro. Assim como a "arte nova" pretendia recolocar a arte em seu caminho histórico, os europeus também deveriam buscar reencontrar o verdadeiro caminho de sua História política e social projetando a formação do "bloco histórico" ${ }^{18}$ em que se constituíra originalmente a Europa.

A solução orteguiana segundo a qual ruptura e continuidade estariam em relação de complementaridade no momento de constituição da obra-de-arte, denuncia, na verdade, a ambigüidade básica do seu pensamento sobre se a Espanha deveria abrir-se para a Europa, conteúdo do moderno, ou fechar-se no tradicionalismo, conteúdo do atraso. Tal era, também, a ambigüidade básica da História contemporânea espanhola que vinha norteando os debates intelectuais desde a constituição das Cortes de Cádiz e do influxo dos pensadores krausistas na primeira metade do século XIX. Se de um lado, a ambigüidade do solo histórico caracteriza um pensamento cheio de tensões e antinomias, de outro lado, tais tensões do pensamento refletem a falta de solução para a convivência entre o "atraso" e a modernidade presente na sociedade espanhola.

O texto de 1925 definiu, dessa forma, o caráter político da arte e, por extensão, da cultura enquanto elemento de problematização e superação da

\footnotetext{
${ }^{18} \mathrm{O}$ termo "bloco histórico" não foi utilizado por Ortega. O autor apenas reporta-se à realidade cultural que, segundo ele, caracterizaria a vida européia no ocidente do continente.
} 
circunstância em que se está inserido. Caberia, então, indagar de Ortega se a sua concepção de arte poderia ser aproximada das teses de Lukács, crítico daquela arte que apenas fotografa a realidade ${ }^{19}$.

Sem dúvida, os dois autores aproximam-se em duas questões fundamentais: preocupam-se com o crescimento das tendências políticas e artísticas que acabam por adulterar a integridade humana deixando-se levar pelos ventos que o capitalismo seguia nas primeiras décadas do século $\mathrm{XX}^{20}$. Além disso, foram profundamente influenciados pela condição de atraso de seus respectivos países, especialmente no que diz respeito à constituição de um Estado liberal ancorado em portadores sociais do discurso produzido pela burguesia no decorrer de sua ascensão aos poderes públicos entre os séculos XVIII e XIX. É sempre bom também lembrar os estudos alemães dos dois autores em suas respectivas fases jovens, durante os anos dez deste século. Nas universidades alemãs do início do século concentravam-se intelectuais marcados pelo pensamento de Georg Simmel segundo o qual o capitalismo teria se constituído sob a égide da transformação do trabalho humano em mercadoria, tornandose estranho ao homem. Tal transformação teria como principal manifestação a tragédia da cultura, "a alienação da cultura objetiva em relação à cultura subjetiva, o avanço da cultura das coisas e o declínio da cultura das pessoas."21

Mas destas premissas chegamos a soluções e projetos bastante diferenciados. Vejamos o que afirma Lukács:

“(...) qualquer tomada de consciência do mundo exterior não é outra coisa senão o reflexo da realidade, que existe independentemente da consciência, nas idéias, representações, sensações, etc., dos homens." ${ }^{22}$

“A verdadeira arte visa o maior aprofundamento e compreensão. (...) apreende exatamente aquele processo dialético vital pelo qual a essência se transforma em fenômeno, se revela no fenômeno, fixando, tam-

\footnotetext{
${ }^{19}$ LUKÁCS, G. Ensaios sobre Literatura. Rio de Janeiro: Civilização Brasileira, 1965.

${ }^{20}$ Do ponto de vista político, os dois autores discutiram o significado da ascensão dos fascismos e do movimento sindical no início do século. No que diz respeito à produção cultural ambos debateram o crescimento das interpretações irracionalistas da História e as relações entre forma e conteúdo na produção artística.

${ }^{21}$ LOWY, M. A evolução política de Lukács: 1909-1929. São Paulo: Cortez, 1998, p. 59.

${ }^{22}$ LUKÁCS, G. Ensaios sobre literatura, op. cit., p. 24-25.
} 
bém, aquele aspecto do mesmo processo segundo o qual o fenômeno manifesta, na sua mobilidade, a sua própria essência." ${ }^{23}$

Definindo a narrativa como expressão dessa convergência e mútua determinação dialética entre a essência e o fenômeno, Lukács pôde, analisando a Literatura do século XIX, especialmente as características assumidas pelo romance, demonstrar a epopéia burguesa que, da conquista do grande público, onde o discurso em favor das liberdades e da igualdade espalhava-se pelo grande mundo, acabou por encerrar-se no pequeno mundo das conquistas particulares ao longo dos anos em que se fortaleceu e expandiu a política imperialista.

Utilizando-se dessa conceituação de narrativa Lukács estabeleceu uma crítica ao naturalismo em Literatura, cuja preocupação estética maior era revelar os meandros da superfície do mundo vivido, e às tendências artísticas que defendiam o extremo oposto: a autonomia das "formas artísticas sobre o real".

Para Ortega a simples observação da realidade corresponderia, parecenos, àquela primeira dimensão do olhar humano sobre a realidade e, neste sentido, podemos afirmar que os dois autores são críticos dos romances naturalistas. O pensador espanhol, porém, mesmo não advogando a total independência das formas artísticas sobre o real, acaba por admitir, e mesmo por sugerir, que o artista consiga separar-se da realidade vivida para propor uma nova realidade. Já Lukács esforça-se por demonstrar o quão distante do ideal de confrontar o homem com seus pares e debater a condição humana estão as vanguardas artísticas do início do século. ${ }^{24}$

Ortega traz para o primeiro plano de sua argumentação a negação da realidade tal como ela se encontrava naquelas primeiras décadas do século. Como pensador liberal vinculado à tradição iluminista que não aceitava as conquistas

\footnotetext{
${ }^{23}$ Ibidem, p. 28-29.

${ }^{24}$ Sobre as teses lukacsianas acerca do fim das grandes narrativas e suas críticas ás "narrativas fragmentadoras" é interessante ler o texto de Jeanne-Marie GAGNEBIN, "Lukács e a crítica da cultura", In: ANTUNES, Ricardo e REGO, W. L. (orgs.) Lukács - Um Galileu no século XX. São Paulo: Boitempo, 1996, pp. 91-96. A autora reflete sobre a polêmica de Lukács com Benjamin e indaga de maneira sugestiva: “(...) criticar o real, criticar a cultura, talvez signifique também criticar as pretensões de universalidade e normatividade de nossos discursos: não para abrir a porta ao irracionalismo ou a um retivismo desenfreado, mas para ter a paciência de perceber como o detalhe, o particular, o anormal, o estranho, o estrangeiro, podem colocar em questão as normas e as totalidades em questão." (GAGNEBIN, op. cit., p. 96.)
} 
da democracia de massas do século XIX, o autor organiza uma crítica da civilização em função da situação social e política do ocidente naquele momento, mais ainda, Ortega preocupa-se com o que denomina de crise da cultura ocidental $^{25}$. Era a cultura, enquanto elemento ordenador e aglutinador da vida social que estava colocada em discussão. Por isso a arte nova das vanguardas do início do século era-lhe tão cara: no seu entender, essas manifestações artísticas partiam da circunstância para compor, mas superavam esta mesma circunstância nos resultados de sua produção artística. É nos resultados artísticos que Ortega encontra projetos de futuro para a Europa, embora não tenha explicitado quais fossem esses projetos.

Lukács, parece-nos, argumentaria que esta segunda dimensão do olhar humano, que Ortega reputa como a verdadeira arte, é impossível, posto que o valor estético da obra de arte estaria, exatamente, na sua unidade com o processo histórico do qual ela não pode ser separada. Qualquer projeto que se queira depreender de uma obra de arte é, antes de tudo, resultado daquela unidade que define a grandeza e o valor da obra ${ }^{26}$. No primeiro plano da argumentação lukacsiana encontra-se, portanto, a unidade indissolúvel entre o valor estético e o processo histórico a partir do qual o artista compõe sua obra. Nesta lógica, as vanguardas do início do século representariam manifestações idealistas de artistas que não possuem uma concepção de mundo clara que lhes possa fornecer o terreno fértil e sólido para a produção verdadeiramente artística. Nesta conceituação idealista se encontraria, também, parece-nos, a argumentação orteguiana. Note-se como Lukács define o artista:

“(...) o grande artista não representa coisas ou situações estáticas, e sim investiga a direção e o rumo dos processos, cumpre-lhe, como artista, definir o caráter de tais processos." ${ }^{27}$

"O escritor precisa ter uma concepção do mundo inteiriça e amadurecida, precisa ver o mundo na sua contraditoriedade móvel, para selecionar como protagonista um ser humano em cujo destino se cruzem os contrários." ${ }^{28}$

\footnotetext{
${ }^{25}$ ADORNO \& HORKHEIMER Dialética do esclarecimento. São Paulo: Zahar, 1985, p. 15.

${ }^{26}$ LUKÁCS, G. op. cit., p. 41-42.

${ }^{27}$ Ibidem, p. 33-34.

${ }^{28}$ Ibidem, p. 78-80.
} 
O escritor, e por extensão o artista lukacsiano, triunfa sobre a realidade quando produz uma obra capaz de desvendá-la, o artista orteguiano triunfa sobre a realidade quando consegue elaborar como que uma alteridade da própria realidade. Note-se que Lukács também aponta certo distanciamento necessário ao grande narrador para operar uma seleção de elementos essenciais na composição da obra de arte, mas este distanciamento é resultado de uma práxis e incorpora o processo histórico à produção artística.

$\mathrm{O}$ olhar externo à realidade a que se refere Ortega vincula-se ao que o autor denomina de reabsorção da circunstância. A negação da realidade presente na obra-de-arte é que vai configurar tal reabsorção na medida em que desperta os leitores para sua circunstância e para as urgências por ela colocadas. Julián Marías comenta o conceito de reabsorção formulado por Ortega:

"La rebsorción de la circunstancia consiste en su humanización, en su incorporación a esse proyecto del hombre; es decir éste se hace a sí mismo com las cosas que le están ofrecidas, hace com ellas vida, las asume proyectándoles sentido, significación, lógos, en suma. El destino del hombre, de cada hombre, cuando es fiel a su situación, es decir, su destino concreto y circunstancial, es imponer a lo real su proyecto personal, dar sentido a lo que por sí solo no lo tiene, extraer el lógos a lo inerte, brutal e ilógico, converter eso que simplesmente hay en torno de mi (circunstancia) en verdadero mundo, en su vida personal. ${ }^{, 29}$

Assim, segundo Ortega, por meio do olhar externo o homem desumaniza sua circunstância e sua produção artística, este seria o momento da concepção do projeto. A humanização da circunstância e da produção artística seria o momento da projeção pública das novas propostas. Podemos afirmar, acompanhando o raciocínio de Ortega, que a obra de arte aparece como um filtro no qual se materializa uma intenção pública de um autor. Ela pode significar a reabsorção do projeto manifesto na obra pela circunstância por meio da atitude dos leitores frente ao herói apresentado em um romance, ao personagem ou à situação social sugerida por um quadro, etc. D. Quixote, neste sentido, seria a maior experiência espanhola de reabsorção da circunstância em seu

${ }^{29}$ MARÍAS, J. Ortega - Circunstancia y vocación. Madri, Alianza Editorial, 1984, p. 400-401. 
momento de desumanização e humanização: Cervantes apresentou um conceito e um projeto de Espanha emblemados na metáfora do Cavaleiro da Triste Figura. Talvez, por ter conferido este significado à obra cervantina, é que Ortega denominou de Meditaciones del Quijote seu primeiro livro, texto no qual pretendeu analisar uma série de "circunstâncias" espanholas, entre as quais a produção literária de Baroja e Azorín.

As atitudes de desumanizar e humanizar a circunstância só seriam possíveis para aqueles homens com vocação para assumir seu próprio destino. Novamente aqui a distinção entre homem e homem-massa aparece como fundamental para compreender as formulações orteguianas. $\mathrm{O}$ homem-massa não possui a consciência da sua circunstância, não seria capaz de desumanizá-la, por isso ele também não compreende a produção artística da chamada arte nova, ele se contenta com a visão material e concreta da realidade, sugerida pelos românticos no entender de Ortega. Por isso, também, a arte nova sequer se destina às massas, ela se destina às elites intelectuais capazes de efetivar as novas propostas. Em Lúkács esta é a mais criticável das características das vanguardas artísticas: a arte deixa de ser um elemento de humanização quando seus conteúdos distanciam-se do solo histórico em que é produzida operando uma separação entre estética e processo histórico. Ao romancista lukacsiano caberia refletir a trajetória dos homens em suas relações sociais, desvendá-la e, dessa forma, apontar para um maior desenvolvimento humano. Tal proposta ancora-se na defesa radical do legado histórico da humanidade que, muitas vezes, encontrava-se em franca contradição com a "disponibilidade para o novo na fruição da arte"30.

Mas, será possível um olhar externo da forma como Ortega sugere? Mesmo dentro da lógica interna do seu pensamento poderíamos opor a questão: como proferir um olhar externo sobre a circunstância se o próprio pensar é caracterizado pelo autor como circunstancialização? Ortega talvez objetasse que o desejo de superar a circunstância seria uma forma de enfrentá-la e não de abstrair-se dela. Mas de qualquer forma restaria a indagação: a produção artística não teria que estar ancorada em uma visão de mundo? Sim, e para tanto, ela não pode prescindir dos necessários nexos entre a essência e o fenômeno presentes nela. A passagem da obra de arte como pedagogia social para a arte

\footnotetext{
${ }^{30}$ KONDER, L., "Estética e política cultural", In: Ricardo ANTUNES e W. L. REGO (orgs.), Lukács - um Galileu no século XX. São Paulo: Boitempo, 1996, p. 28.
} 
como distanciamento da realidade negada em seu texto, não resolveu o problema das relações entre a visão de mundo do artista e as formas de representação artística escolhidas exatamente porque, para Ortega, o primeiro argumento político e cultural daquele início de século deveria ser a negação da realidade que havia produzido os movimentos sindicais, de um lado, e o fascismo, de outro. Desta forma, contra o artista que refletia em sua obra as contradições de uma realidade cujos produtos sociais apontavam para enfrentamentos sociais e para o crescimento dos movimentos populares, ele afirmava a idéia de que não produzia verdadeira arte. $\mathrm{O}$ artista encontra-se no grupo dos intelectuais que, no entender de Ortega, tinham a dupla função de decodificar a circunstância para a massa e sugerir sua alteração em um projeto político definido.

Retornamos, assim, ao tema das antinomias, ou tensões, como se queira, do pensamento orteguiano. Cabe, então, tentar avançar desta constatação para uma possível explicação.

\section{0 autor, sua obra e sua visão de mundo}

Ortega expressava, em sua visão de mundo, um profundo descontentamento com os rumos políticos e sociais da Espanha e da Europa. Seu projeto político maior foi a regeneração espanhola por meio de uma pedagogia social voltada para a formação de elites dirigentes e que pudesse levar o país a superar seu atraso frente ao processo político e cultural dos países centrais da Europa, especialmente a Alemanha e a Inglaterra. Essa proposta de regeneração tinha por base a concepção de que a Europa ocidental possuía elementos culturais comuns que sustentariam a formação de uma só Europa. Regenerar a Espanha, ou vertebrar em outras palavras, e unificar a Europa, estes os dois pilares que ancoravam seu projeto político. Neste sentido, toda sua produção intelectual objetivava demonstrar o significado histórico deste projeto. Daí sua preocupação em fundamentar suas teses em dois pontos básicos: primeiro, a divisão social entre homens, capacitados para o exercício do poder público, e massas, relegadas à condição de seguidoras dos grupos iluminados, de onde decorre sua especial atenção ao papel dos intelectuais em sociedades consideradas atrasadas; segundo, a necessidade de um conjunto de usos e costumes que permitam à sociedade identificar-se como tal, em outras palavras, a existência de um conjunto cultural que opere como referencial para todos os grupos sociais que compõem a nação.

Seria possível encontrar um eixo de análise no qual a produção orteguiana reflita, tal como a de Thomas Mann no entender de Lukács, as agruras de um país 
cuja única via de acesso para a construção do Estado liberal tenha sido a via prussiana, a via que nega os princípios originários do próprio liberalismo? Vejamos.

Ortega, como homem político e narrador do seu tempo, não conseguiu resolver o problema do atraso espanhol no âmbito da sua produção intelectual. O atraso, visto como deserção das elites no que diz respeito à gestão dos poderes públicos e à elaboração de projetos de futuro para o país, teria como solução a formação de novas elites intelectuais capazes de exercer o poder de forma a construir uma Espanha afinada com o que o autor denominava de "nível cultural europeu". Tal intenção não se realizou, mesmo com os esforços da Liga de Educación Política espanhola. No âmbito de sua atuação política menos ainda, o grupo de 1913 ao qual pertenciam a maioria dos republicanos de linha liberal conservadora como Ortega, participou do processo de construção da república espanhola após 1930 por poucos anos e o nosso autor acabou por abrigar-se no seio de sua produção intelectual. Os projetos de linha socialista e ditatorial mostraram-se mais competentes na tarefa de encontrar portadores sociais para os seus respectivos discursos.

Lukács nos apresenta um Thomas Mann preocupado com a experiência do isolamento do indivíduo resultante da evolução da sociedade burguesa sob a ordem imperialista:

“(...) o que em Schiller era o simples reflexo do atraso alemão, da imaturidade objetiva e subjetiva da Alemanha para uma transformação democrática, possui hoje (momento em que Mann escreve) um acento inteiramente novo, o da incredulidade e desconfiança na atividade das massas, nas possibilidades criadoras que provêm de baixo." ${ }^{31}$

Mann é autor de um tempo em que o indivíduo, subsumido no âmbito da atuação das massas, não encontra espaço para desenvolver idéias e praticar as regras do jogo democrático. É neste contexto que a via prussiana adquire viabilidade social posto que os postulados democráticos não constituíram nenhum "grande mundo" autóctone na Alemanha pós 1848. Da mesma forma, é neste contexto que o intelectual enclausura-se no seu pequeno estúdio de feitiçarias.

${ }^{31}$ LUKÁCS, G., op. cit., p. 188-90. 
"O estúdio do novo Fausto (...) visto do exterior, parece bem mais hermeticamente fechado ao externo mundo social; porém, na realidade, ele é um laboratório de feitiçarias, no qual todas as tendências perniciosas da época são refinadas até sua expressão mais concentrada. (...) No pequeno mundo deste estúdio está contida a quintessência do mundo que a espiritualidade alemã possui na sua 'interioridade à sombra do poder', na sua compreensão de si, (...). Este estúdio é o sucedâneo do grande mundo da intelectualidade alemã do período imperialista." ${ }^{32}$

A universalidade do texto manniano estaria no fato de que a crise da democracia não era apenas alemã, era universal, pois engendrou críticas à democracia, oposição à democracia e a problematização interna ao discurso democrático mesmo. A democracia acaba sendo responsabilizada, inclusive, e tal é o discurso orteguiano, pela decadência da Europa ocidental ${ }^{33}$ do início do século. No caso alemão, e por extensão, acreditamos, no caso espanhol, o atraso na constituição do Estado liberal justificaria a maior radicalidade com que a crise é enfrentada e, mesmo, as propostas de inversão total dos valores democráticos, especialmente os fascismos.

Note-se, porém, que Lukács define o texto manniano como característico daquele movimento intelectual do grande mundo das barricadas para o pequeno mundo do estúdio e, mais ainda, o texto manniano parece ser crítico desta tendência pois se bate contra a perda da individualidade no plano da ação social. A desumanização, entendida como encerramento no estúdio e como "dissolução do grande mundo", que caracterizaria a produção intelectual e artística do período era vista por Mann, e mesmo por Lukács, como barbárie.

Ortega utiliza-se da percepção desta desumanização para construir um conceito positivo de arte, aquele em que a arte teria por função afastar-se do real para buscar sua alteração. Mann, ao contrário, e daqui Lukács constrói sua crítica às vanguardas modernistas, enxerga sua época como desfavorável à arte exatamente porque para realizá-la seria necessário "romper resoluta e ativamente" com o tempo vivido.

\footnotetext{
${ }^{32}$ Ibidem, p. 195.

${ }^{33} \mathrm{Na}$ análise culturalista de Ortega tal crise ancora-se na perda dos valores fundadores do ocidente, a saber, a "concórdia" e a "vida como liberdade". Veja-se: Ana Lúcia Lana NEMI, "As bases culturais da ocidentalização no pensamento de José Ortega y Gasset e a influência de suas idéias na República brasileira dos anos 20 e 30", In: Revista Ciência e Trópico, Volume 24, no 02, Jul./Dez. de 1996, p. 359-383.
} 
O isolamento do indivíduo tem, para Ortega, uma leitura negativa na medida em que denuncia a ascensão das massas ao cenário político espanhol e europeu. Não era possível ao indivíduo viver e expressar a sua individualidade porque o "soberano" estaria sempre a cobrar a conivência do indivíduo para com o interesse coletivo. De outro lado, Ortega considera o momento vivido pela sua geração como de "elevação do nível histórico" 34 e, como tal, sugere elementos positivos a serem analisados. Em sua conceituação de arte o elemento positivo da Europa do início do século fica claro: o isolamento seria a condição necessária para a negação da realidade, postura fundamental em seu pensamento. Na condição de isolamento o intelectual poderia projetar outra "circunstância" reabsorvendo a sua própria.

Na análise que Lukács nos oferece de Mann, o isolamento seria a indicação da impossibilidade da arte e da atuação pública dos intelectuais. No âmbito da obra de Mann, anulam-se os vínculos entre a sociedade e o próprio texto. Mesmo quando busca uma síntese entre fenômeno retratado e essência discutida o autor encontra apenas decomposição e esfacelamento. Tal busca de síntese atinge seu ápice quando chega a ser busca da ordem a qualquer custo, este é o momento da quebra de qualquer possibilidade de constituição do Estado liberal. Também para Ortega, a impossibilidade de evitar a ascensão dos movimentos políticos vinculados às massas aponta a impossibilidade de constituir um Estado liberal na Espanha. ${ }^{35}$

"Esta aspiração à ordem e à síntese, que nasce da moderna desagregação do individualismo, mas que permanece puramente subjetiva, chega assim a aflorar continuamente, do ponto de vista conceitual e ideológico, aquelas tendências que conduzem ao reforçamento da reação imperialista. Ou antes, diretamente: ao fascismo. Nisto se manifesta a imanente predisposição da arte moderna, como síntese formal, às ideologias reacionárias da época." ${ }^{36}$

\footnotetext{
${ }^{34}$ ORTEGA Y GASSET, José. A Rebelião das Massas. São Paulo: Martins Fontes, 1989, p. 43-50.

${ }^{35}$ O termo "quebra do Estado liberal" foi cunhado por Fernando ARIEL del VAL em Historia e ilegitimidad. La quiebra del estado liberal en Ortega, Madri, Editorial de la Universidad Complutense, 1984. Neste texto o autor procura demonstrar exatamente este processo por meio do qual o pensamento orteguiano caminha no sentido de negar as conquistas do Estado liberal em função da urgência de garantir a ordem ou, em outras palavras, evitar a efetivação do poder soberano - entendido por Ortega como o poder que seria exercido pelas esquerdas.

${ }^{36}$ LUKÁCS, G., op. cit., p. 203.
} 
Da mesma forma que a trajetória dos personagens de Mann indica uma "identificação passiva" com a ascensão dos movimentos reacionários que imporiam a "ordem a qualquer custo", o silêncio e o exílio voluntário de Ortega após a vitória franquista também pode ser interpretado como "falta de defesa" diante dos movimentos reacionários que dominaram a Espanha e parte da Europa do período. Na "atmosfera intimista" do seu pequeno mundo, Ortega abstevese de enfrentar o regime de Franco ${ }^{37}$. Mas é exatamente deste encerramento no pequeno mundo que decorre a impotência dos intelectuais para o exercício de qualquer função pública naqueles conturbados anos das três primeiras décadas deste século. O pequeno mundo abre todas as possibilidades de "feitiçaria": projetos, teorias, análises, experiências, racionalismos e irracionalismos, etc., mas nenhuma encontra eco no novo mundo que estava sendo gestado pois nenhuma é resultado de práxis social. Mas, há que se ressaltar, Ortega, ao contrário de Lukács, nunca deixou muito claro seu posicionamento frente aos fascismos. Embora tenha escrito contra os fascismos ${ }^{38}$, admitia a hipótese de ascensão política destes movimentos para conquista da tão propalada ordem ${ }^{39}$.

Assim, a única possibilidade de ordem seria o estabelecimento do Estado liberal pela via prussiana, a via que anula a participação das massas dos processos de decisão política. Mas tal via "pelo alto" é, também, uma via de mão dupla: o mesmo Estado que alija as massas de si é o Estado que se precipita sobre a sociedade e nega-lhe o princípio da liberdade quando a sociedade demonstra querer voltar-se contra ele. Este o fenômeno que Adrian discute com seu biógrafo no âmbito do seu estúdio. Esta a realidade que envolveu as duas gerações de intelectuais (1898 e 1913) com as quais militou Ortega em favor da liberdade e do individualismo e contra o predomínio das massas nos poderes públicos. Certamente, e não por acaso, foram os estudos na Alemanha que deram fundamento para o culturalismo de Ortega no plano político: é a experiência de viver em sociedades que sofrem as agruras do atraso na constituição do Estado

\footnotetext{
${ }^{37}$ Cabe lembrar que Ortega retornou do seu exílio em 1945, quando foi recebido pelos opositores de Franco como representante das lutas do liberalismo contra os regimes autoritários. Tal atitude das oposições espanholas pode ser interpretada como um posicionamento mais marcadamente político do que propriamente ideológico em relação ao pensamento orteguiano. Muitos pensadores espanhóis, inclusive, consideravam a atitude passiva de Ortega frente ao regime nos anos de 1940-45 como apoio disfarçado. ${ }^{38}$ ORTEGA Y GASSET, A Rebelião das Massas, op. cit., p. 103-110.

${ }^{39}$ ARIEL DEL VAL, F., História e ilegitimidad..., op. cit.
} 
liberal que fundamenta a reflexão sobre o papel dos intelectuais e sobre a atitude de isolamento característica de boa parte dos intelectuais do período em questão.

\section{Modernidade e fragmentação}

"Lo que Ortega consideraba la estructura funcional básica de la acción social, estaba constituido por la acción de los hombres más energéticos sobre las masas posibilitada por los vínculos comunes y la mediación de la generación, verdadero cuerpo social. Para Lukács toda acción sobre las masas requiere la organización del partido. Ambos consideran, sin embargo, que esta acción es de urgente realización, que la teoría debe guardar consonancia com el verdadero sentir de las masas y sus legítimos intereses." 40

Nos anos 20 do século XX Lukács e Ortega estavam preocupados com a possibilidade de ação política e cultural consciente das camadas populares, mas o primeiro estuda os caminhos do desenvolvimento da consciência de classe no meio operário, enquanto o segundo sugere explicitamente a falta de condições intelectuais das massas para o exercício da política institucional. Por isso, em História e consciência de classe ${ }^{41}$, publicado em 1923, Lukács ressalta a urgência da organização da classe operária que fará o papel de vanguarda da revolução: é ela que prepara a tomada do poder porque só o proletariado pode ser sujeito e objeto do seu conhecimento. No mesmo ano de 1923 Ortega publica El tema de nuestro tiempo ${ }^{42}$, dois anos antes de La deshumanização del arte, mas a sua urgência aponta para a educação das massas de maneira a aceitar o recorte social entre massas e minorias, posto que a consciência de fato, esta seria privilégio das elites intelectuais a quem o poder político deveria ser entregue. Como Ortega não define socialmente os agentes sociais que efetivarão seu projeto, fica-nos sempre a impressão de estar faltando algum argumento no seu texto.

\footnotetext{
${ }^{40}$ RANCH, E., op. cit., p. 238.

${ }^{41}$ LUKÁCS, G., História e consciência de classe. São Paulo: Martins Fontes, 2003.

42 José ORTEGA Y GASSET, "El tema de nuestro tiempo", In: Obras Completas, op. cit., vol. III, pp. 141-230.
} 
Como imaginar elites intelectuais desvinculadas de seu lugar nas relações de produção? Quem seriam estes componentes das elites? A referência ao esclarecimento intelectual como critério de definição das elites parece insuficiente... Já Lukács aponta claramente os agentes sociais que efetivarão o seu projeto: a posição de classe do proletariado é o local privilegiado a partir do qual se pode perceber a realidade social. Ortega é um perspectivista e, enquanto tal, não acredita na existência de um local social privilegiado a partir do qual possamos compreender a realidade social. Por isso, enquanto Ortega sugere a "geração", definida pela urgência no enfrentamento das questões colocadas pela altura do tempo vivido, Lukács sugere o proletariado como portador do discurso que irá transformar a sociedade e recolocar a liberdade como conteúdo substantivo da nova ordem social. Os dois autores, do ponto de vista dos conteúdos de suas reflexões, partem de observações sobre a consciência e a visão de mundo das camadas populares, a massa para Ortega e o proletariado para Lukács, e, com base nessas observações, sugerem uma leitura da arte e da ação dos homens de cultura. Mas, de novo os vetores indicam soluções opostas: o primeiro autor acredita nas muitas significações possíveis da obra-de-arte moderna que dialoga com a fragmentação, o segundo busca a grande arte na totalidade que reúne essência e fenômeno, conteúdo e forma. Interessante notar que, para Lukács, a classe operária pode ser revolucionária exatamente porque é herdeira das tradições culturais da humanidade, a ruptura só é possível dentro dos parâmetros de compreensão e leitura do mundo inscritos nessa tradição.

Essas diferenças apontam para o tema da modernidade: podemos arriscar afirmar que o pensamento lukacsiano encontra-se no âmbito da modernidade pois tem a razão como elemento fundamental. Já o pensamento orteguiano, buscando fugir da dicotomia que ele denomina moderna e que, segundo ele, opõe razão e vida, relativiza os conceitos em função da realidade vivida - ou da circunstância, como diria o próprio Ortega. Enquanto Lukács busca na tradição moderna a vontade de ruptura e construção do "completamente novo" por cima dos "escombros do passado", Ortega procura mostrar a modernização como um processo de mudança social pelo qual uma sociedade abandona sua feição tradicional para alcançar a modernidade. Mas, neste último autor, modernidade e tradição não seriam excludentes: o mesmo processo de modernização que, em tese, deveria romper com a tradição, traz em si elementos da tradição evidenciados na diversidade circunstancial que caracteriza as várias realidades sociais. Não seria possível, portanto, falar em uma modernidade, mas em "modernidades circunstanciais". 
"La modernidad no es un concepto sociológico, ni un concepto político, ni propiamente un concepto histórico. Es un modo de civilización característico, que se opone al modo de la tradición, es decir, a todas las demás culturas anteriores o tradicionales: frente a la diversidad geográfica y simbólica de éstas, la modernidad se impone como una, homogénea, radiante a partir del Occidente. (...) Inextricablemente mito y realidad, la modernidad se concreta en todos los dominios: Estado moderno, técnica moderna, música y pintura modernas, costumbres y ideas modernas." ${ }^{43}$

A "expansão" da modernidade ocidental a partir do século XVI, na lógica orteguiana, foi homogênea na expansão dos seus produtos, mas não na percepção da historicidade destes produtos pelas várias sociedades que foram "invadidas" pelo estilo moderno de vida e cultura ${ }^{44}$. $\mathrm{O}$ autor aponta para a inexistência de uma modernidade absoluta e, consequientemente, a impossibilidade da ruptura total proposta pelas revoluções comunistas. A modernidade explica-se pela continuidade histórica que ela denuncia, não pelas rupturas que anunciou, é como se ela gestasse uma "novidade acumulada", não uma "novidade pura".

Ortega fundamenta, assim, uma concepção ambígua da modernidade onde assumir os pressupostos da vida moderna significa, também, considerá-los como parte da tradição que eles pretendem superar. Seu projeto de educação das massas para o conhecimento da cultura acumulada que teria permitido a conquista dos direitos políticos e civis, era uma definição clara de militância em favor do reformismo social e do "liberalismo ético, cultural y político" 45 em oposição aos movimentos sindicais e fascistas baseados, em sua concepção, na projeção de rupturas com a História.

Mas o texto de Ortega limita-se a constatar a urgência da ação organizada para o fortalecimento das instituições liberais, o autor não aponta caminhos e atitudes práticas que poderiam viabilizar tal proposta. A educação das massas mostrou-se ineficiente e não chegou a ter um número de adeptos que pudesse, sequer, viabilizar a proposta a contento. Lukács, ao contrário, afirmou a importância dos conselhos de fábrica, num primeiro momento, e a urgência de reformas

\footnotetext{
${ }^{43}$ AZAM, G. "Ortega y Gasset, crítico de la modernidad”, In: Actas del III Seminario de Historia de la Filosofía española. Ediciones Universidad de Salamanca, 1983, p. 300.

${ }^{44}$ ORTEGA Y GASSET, José, A rebelião das massas, op. cit.

${ }^{45}$ DÍAZ, E. “Ortega y la Institución Libre de Enseñanza”, In: Revista de Occidente, Fundación Ortega y Gasset de Madri, 4ª época, nº 68, jan. 87, p. 123.
} 
democráticas em momentos de refluxo do movimento revolucionário ${ }^{46}$. A geração orteguiana é um conceito que permite o estudo de projetos políticos e proposições culturais em épocas históricas definidas, mas não pode ser vista como um projeto político claro de intervenção no plano político-institucional.

Há que se destacar, a partir das analogias e oposições aqui apontadas, um certo "tom geracional" na produção de Lukács e Ortega. Formados ambos no contexto dos debates dos anos 10 e 20 que encontraram na Alemanha fundamento e solo histórico para se desenvolver, os dois autores foram profundamente marcados pela situação social de seus respectivos países que possuía, senão outras, pelo menos uma importante semelhança que vale destacar. A condição de atraso no que diz respeito à constituição do Estado liberal e à organização capitalista da produção deu origem a movimentos populares que aliavam as tarefas tradicionais de oposição ao Antigo Regime - agindo como revolucionários burgueses e reivindicando liberdades civis e direitos políticos - com as tarefas tradicionais de oposição à ordem burguesa propriamente dita - agindo, ora como revolucionários vinculados ao proletariado, ora como herdeiros da tradição conservadora que, no início do século XIX, buscara construir uma contra-lógica ao racionalismo burguês. Assim, intelectuais como José Ortega y Gasset e os autores vinculados ao 1898 espanhol assumem a ambígua postura de serem contra o Antigo Regime e anticapitalistas ao mesmo tempo, defendem o voto universal mas desconfiam das reais possibilidades de conquistarem a liberdade e a justiça social por meio dele ${ }^{47}$.

Lowy aponta uma radicalização anticapitalista da intelectualidade centroeuropéia nos anos 10 e 20 deste século. A oposição entre cultura e civilização, que teria sido operada pela modernidade por meio do capitalismo, agredia o intelectual na medida em que, quantificando a cultura, conferia valor de troca a obras-de-arte. Esta postura é especialmente marcante na Alemanha onde as camadas sociais "atingidas no seu modo de vida, e nos seus interesses, pelo

\footnotetext{
${ }^{46} \mathrm{O}$ texto História e consciência de classe, citado na nota 40, sugere os conselhos de fábrica, já as Teses de Blum, de 1928, destaca o refluxo do movimento revolucionário e sugere a organização democrática no lugar da imediata tomada de poder pela classe operária.

${ }^{47}$ LOWY, M., op. cit, p. 93. Vale ressaltar que Lowy está preocupado apenas com a situação da Hungria pois seu objeto de estudo é a evolução do pensamento de Lukács. São os textos de Julián Marías e Gil Villegas - Los profetas y el mesías - Lukács y Ortega como precursores de Heidegger en el zeitgeist de la modernidad (1900-1929). México: Fondo de Cultura Económica, 1996 - além das leituras de autores espanhóis como Pérez de Ayala e Azaña, que nos autorizam a sugerir um paralelo entre o comportamento dos intelectuais espanhóis e húngaros face à realidade social que viviam.
} 
desenvolvimento do capitalismo" formaram uma forte base social de crítica aos produtos sociais e culturais do capitalismo ${ }^{48}$. De um lado, e nisso são legítimos herdeiros do romantismo, os intelectuais evocam as antigas tradições destruídas pelo avanço do racionalismo e da organização capitalista da produção e da política. De outro, ou ao mesmo tempo, criticam a falta de comprometimento das populações vinculadas às formas de trabalho capitalistas para com o que denominam "cultura" em seu sentido universal.

Essas antinomias caracterizam sociedades onde o desenvolvimento do capitalismo não esteve marcado por uma destruição clara da antiga ordem e pela organização política de uma classe social que fizesse o papel de vanguarda e portadora do discurso revolucionário. Pode-se, nesta lógica, afirmar certo paralelismo entre o posicionamento ambíguo da intelectualidade centro-européia e a ilusão da intelectualidade que formou as gerações de 1898 e de 1913 na Espanha. A estes intelectuais espanhóis não interessava a definição das relações de trabalho e as manifestações culturais que representassem recortes do tecido social. Advogavam o fim dos resquícios da antiga ordem que havia sido construída durante o século de ouro mas, muitos deles, enalteciam os feitos espanhóis do século XVI quando toda a nação teria se comprometido com um mesmo projeto de vida pública. Criticavam a sociedade industrial composta por iletrados e pouco comprometida com a cultura, mas defendiam os direitos inaugurados pelo projeto liberal-burguês do século XVIII.

Buscando redimir a nação por meio da educação, estas gerações, que tiveram em Ortega um importante porta-voz, acreditaram, especialmente a de 1913, poder tomar os poderes públicos com seu projeto regeneracionista sem estar vinculada a nenhuma classe social que pudesse ancorar socialmente suas propostas. Talvez seja esta a principal característica da intelectualidade dos anos 10 e 20 que participou dos círculos universitários alemães da época guilhermina e da belle époque e que era oriunda de países ditos "atrasados" como a Alemanha, a Espanha e a Hungria: acreditar poder redimir a nação de seu atraso constituindo um Estado, e por consequiência uma nação, segundo os diagnósticos e soluções apresentados por intelectuais ou "homens de cultura"49.

\footnotetext{
${ }^{48}$ Ibidem, p. 30-33.

${ }^{49}$ É Gil Villegas quem desenvolve a hipótese de Ortega e Lukács terem compartilhado o mesmo ambiente intelectual na Alemanha guilhermina que teria influenciado fortemente seus pensamentos na juventude e composto o "espírito do tempo" que configurou suas respectivas produções intelectuais. Tal ambiente partilhado justificaria o fato de ambos poderem ser considerados precursores de Heidegger. GIL VILLEGAS, op. cit., p. 13.
} 
Narrador do seu tempo, Ortega pretendeu, de um lado, redimir a nação dos seus males com teses que podemos reputar iluministas na medida em que acreditava que certa pedagogia social evitaria o enfrentamento e a barbárie. De outro lado, advogava a hierarquia entre massas e elites esclarecidas como fundamento da organização social. Progresso e resistência são duas componentes do seu pensamento assim como são elementos constitutivos da sociedade espanhola pós Antigo Regime.

\section{Observações finais}

Talvez valha a pena finalizar alargando a reflexão que tentamos fazer aqui para o mundo ibérico. Cabe lembrar, em primeiro lugar, a advertência de J. S. da Silva Dias ao analisar o pensamento português do século XVIII:

"Revolução e restauração, progresso e resistência, são constantes do pensamento e da história. E não é das tarefas mais fáceis do investigador descobrir a opção retardatária debaixo da máscara progressista, ou, pelo invés, descobrir a opção progressista debaixo da máscara retardatária." ${ }^{50}$

É exatamente esse tema das relações entre progresso e resistência que fundamentou a ação dos homens de cultura que, no final do século XIX e início do XX, pretendiam apontar os caminhos da modernização nacional. Neste sentido, cabe lembrar, em segundo lugar, que a capacidade de operar mudanças sociais foi a principal inspiração para escrever e para a ação social de gerações de homens de cultura que, entre o final do XIX e o início do XX, e especialmente em sociedades arcaicas que se modernizam rapidamente, pretenderam regenerar suas respectivas nações ${ }^{51}$.

No caso específico de José Ortega y Gasset (1883-1954) sua defesa da “arte nova" como elemento de fundação de novas realidades e sua atuação em favor de certa "pedagogia social" capaz de redimir a Espanha do seu atraso, ao mesmo

\footnotetext{
${ }^{50}$ SILVA DIAS, J. S. "O ecletismo em Portugal no século XVIII: gênese e destino de uma atitude filosófica", In: Revista Portuguesa de História, ano VI, 1972.

${ }^{51}$ SEVCENKO, Nicolau, Literatura como missão - Tensões sociais e criação cultural na Primeira República. São Paulo: Brasiliense, 1995, pp. 80-81. Ver também: SEVCENKO, N. "O fardo do homem culto: Literatura e Analfabetismo no Prelúdio Republicano", In: Revista de Cultura Vozes, n. 09, nov. 1980.
} 
tempo em que advogava a hierarquia entre massas e elites, tornam a tarefa do investigador que busca "desembaralhar" os imbricamentos entre progresso e resistência fundamental para entender as apropriações e leituras dos seus textos: o autor foi usado como fundamento para posicionamentos liberal-democráticos e para posicionamentos francamente afinados com as teses franquistas. ${ }^{52}$

Teófilo Braga (1843-1924), intelectual português que participou das Conferências do Casino Lisbonense de 1871, foi membro fundador do Partido Republicano Português em 1876 e presidente da República fundada em 1910, também emblema essa atitude que reúne progresso e resistência na ação pública: o mesmo PRP que deveria apontar e construir o progresso ajudou a sacralizar o Império, dirigido de maneira concreta para a África depois das pautas de 1892 , e a fundar a República excludente de $1910 .{ }^{53}$

E o que dizer de Paulo Prado (1869-1943), a sugerir no seu Retrato do Brasil $^{54}$ a tristeza como traço distintivo do caráter nacional e uma certa "revolução" que refundaria a república, a olhar o Brasil como homem de negócios representante da melhor burguesia paulista? Progresso ou resistência ele retira das suas leituras de Capistrano de Abreu e Oliveira Martins?

Mas essas últimas são indagações que, embora se inspirem na mesma matriz que originou essas poucas sugestões de leitura em torno de José Ortega y Gasset e Georg Lukács, já vão muito além das nossas pretensões iniciais e ficam, portanto, para serem desenvolvidas em outro momento.

\footnotetext{
${ }^{52}$ Cf. ARIEL del VAL, F. Historia e ilegitimidad ..., op. cit. Nota 35; e ELORZA, A. La razón y la sombra..., op. cit. Nota 03.

${ }^{53}$ BRAGA, Teófilo, História da Literatura portuguesa, Lisboa, Coimbra e Porto: Imprensa Nacional - Casa da Moeda, 1984, 4 vols. (1 $1^{\text {a }}$ edição do primeiro volume: 1870) e Soluções positivas da política portuguesa. Porto: Lello \& Irmãos, 1913 ( $1^{\text {a }}$ edição é de 1879). Sobre o tema do Terceiro Império nas elites intelectuais e republicanas do final do XIX e início do XX: ALEXANDRE, Valentim. Origens do colonialismo português moderno, Lisboa: Sá da Costa, 1979, e Velho Brasil, Novas Áfricas. Lisboa: Afrontamento, 2000; e SERRÃO, Joel. Liberalismo, socialismo, republicanismo - antologia de pensamento político português. Lisboa: Livros Horizonte, 1979.

${ }^{54}$ PRADO, Paulo. Retrato do Brasil. São Paulo: Cia. das Letras, 1997 (1 a edição de 1927).
} 